Ettledorf, J. N., et al. (1967). Fournal of Pediatrics, 70, 758.

Fairley, K. F., Barrie, J. U., and Johnson, W. (1972). Lancet, 1, 568

Fosdick, W. M., Parsons, J. L., and Hill, D. F. (1969). Arthritis and Rheumatism, 12, 663 .

Grupe, W. E., and Heymann, W. (1966). American fournal of Diseases in Children, 112,448 .

Hoover, R., and Fraumeni, J. F. (1973). Lancet, 2, 55.
Hyman, L. R., and Gilbert, E. F. (1972). Lancet, 2, 426.

Johnson, W. W., and Meadows, D. C. (1971). New England fournal of Medicine, 284, 290.

Kumar, R., et al. (1972). Lancet, 1, 1212.

McCrory, W. W., et al., (1973). Fournal of Pediatrics, 82, 614.

Meadow, S. R., Weller, R. O., and Archibald, R. W. R. (1969). Lancet, 2,876 .
Moncrieff, M., et al. (1969). British Medical fournal, 1, 666.

Rapola, J., et al. (1973). Lancet, 1, 98.

Scheinman, J. I., and Stamler, F. W. (1969). Fournal of Pediatrics, 74, 117. Schmähl, D. (1967). Deutsche medizinische Wochenschrift, 92, 1150.

Spitzer, A. (1972). Pediatric Research, 6, 330.

Tannenbaum, H., and Schur, P. H. (1974). Arthritis and Rheumatism, 17, 15.

Tsao, Y. C., and Yeung, C. H. (1971). Archives of Disease in Childhood, 46, 327 .

Uldall, P. R., et al. (1972a). Lancet, 1, 1250

Uldall, P. R., Kerr, D. N. S., and Tacchi, D. (1972 b). Lancet, 1, 693.

Walker, S. E., and Bole, G. G. (1973). Fournal of Laboratory and Clinical Medicine, 82, 619.

Warne, G. L., et al. (1973). New England fournal of Medicine, 289, 1159.

Worth, P. H. L. (1971). British Medical fournal, 3, 182.

\title{
Glomerulonephritis Associated with Antibody to Glomerular Basement Membrane
}

\author{
J. G. P. SISSONS, D. J. EVANS, \\ I. J. SIMPSON, M. MACANOVIC \\ A. J. EISINGER, J. M. BOULTON-JONES,
}

British Medical fournal, 1974, 4, 11-14

\section{Summary}

Glomerulonephritis associated with antibody to glomerular basement membrane, shown by linear staining of the glomerular basement membrane with fluoresceinated antiIgG antisera, was found in only 10 out of $400(2.5 \%)$ renal biopsy specimens studied by immunofluorescence. Seven of these cases had rapidly progressive glomerulonephritis, five with lung haemorrhage (Goodpasture's syndrome) and two without, and three had less severe nephritis without lung haemorrhage. Circulating antibody to glomerular basement membrane, measured by a passive haemagglutination technique and by indirect immunofluorescence, was detected in the serum of all patients with rapidly progressive glomerulonephritis by both techniques but only by the passive haemagglutination method in two of the other three patients. Two patients died of their lung haemorrhage, one despite bilateral nephrectomy, and lung haemorrhage and circulating antibody to glomerular basement membrane persisted after bilateral nephrectomy in another patient.

\section{Introduction}

In most cases of human glomerulonephritis immunofluorescent staining shows immunoglobulin in the glomeruli, usually as fine granular deposits or irregular aggregates, an appearance taken to indicate immune-complex deposition. A much less common immunofluorescent appearance is that of linear staining of the glomerular basement membrane (G.B.M.) with antisera to IgG, this finding being characteristic of anti-G.B.M. antibody deposition. We describe here

Royal Postgraduate Medical School, Hammersmith Hospital,

J. G. P. SISSONS, M.B., M.R.C.P., Registrar, Department of Medicine D. J. EVANS, M.B., Senior Lecturer in Pathology

D. K. PETERS, M.B., M.R.C.P., Lecturer in Medicine and Immunology

J. M. BOULTON-JONES, M.B., M.R.C.P., Senior Registrar, Department of Medicine

I. J. SIMPSON, M.B., M.R.C.A.P., Research Fellow, Department of Medicine M. MACANOVIC, M.D., Research Fellow, Department of Medicine

St Helier Hospital, Carshalton, Surrey

A. J. EISINGER, B.A., M.B., Consultant Physician

our experience of patients with glomerulonephritis associated with linear deposition of IgG along the G.B.M. in whom it seemed anti-G.B.M. antibody might play a pathogenetic role. To provide additional evidence for such a role we also examined the sera of these patients for anti-G.B.M. antibody.

\section{Methods}

Renal tissue was obtained by percutaneous needle biopsy in most patients and in some patients at nephrectomy or at necropsy. Specimens were processed for light microscopy examination by conventional techniques. Tissue for immunofluorescent studies was processed as described previously (Evans et al., 1973).

Sera were examined for the presence of anti-G.B.M. antibody by passive haemagglutination, in which human red cells, coated with human G.B.M., were studied for agglutination by test sera, as described by Macanovic et al. (1972), and by indirect immunofluorescence. For this technique cryostat sections of fresh frozen Rhesus monkey kidney were exposed to serial dilutions of test sera in phosphate buffered saline, washed in the saline, stained with a fluoresceinated monospecific antihuman IgG antiserum, and examined as for routine immunofluorescence. The appearance of linear staining of the G.B.M. was taken as evidence of anti-G.B.M. antibody in the test serum. Controls included sections washed with phosphate buffered saline alone and sera from normal subjects and patients with other types of nephritis, and these always gave negative results.

Elution of antibody from whole kidney was attempted in two cases by a similar method to that of Wilson and Dixon (1973). Elution of antibody from cryostat sections was performed by the method of Feltkamp and Boode (1970).

\section{Patients}

The cases were selected from all patients whose renal biopsy specimens were studied by immunofluorescence in our unit (about 400 renal biopsies) because they showed linear staining of the G.B.M. for IgG. Two patients (cases 4 and 5) were referred to the renal unit of St. Helier Hospital and the remaining eight to the renal unit at Hammersmith Hospital. Details of the cases are given in table I. Antistreptolysin $\mathbf{O}$ titres and plasma C3 levels were normal and antinuclear fac- 
TABLE I-Clinical Details of Patients

\begin{tabular}{|c|c|c|c|c|c|c|c|c|}
\hline \multirow{2}{*}{$\begin{array}{l}\text { Case } \\
\text { No. }\end{array}$} & \multirow{2}{*}{ Sex } & \multirow{2}{*}{ Age } & \multirow{2}{*}{ Renal Syndrome } & \multirow{2}{*}{ Lung Syndrome } & \multicolumn{4}{|c|}{ Data on Presentation } \\
\hline & & & & & $\begin{array}{l}\text { Haemoglobin } \\
(\mathrm{g} / 100 \mathrm{ml})\end{array}$ & $\begin{array}{l}\text { Blood Urea } \\
(\mathrm{mg} / 100 \mathrm{ml})\end{array}$ & $\begin{array}{l}\text { Chest } x \text {-ray } \\
\text { Appearances }\end{array}$ & $\begin{array}{l}\text { Blood Pressure } \\
(\mathrm{mm} \mathrm{Hg})\end{array}$ \\
\hline $\begin{array}{l}1 \\
2\end{array}$ & M. & $\begin{array}{l}60 \\
26\end{array}$ & $\begin{array}{l}\text { R.P.G.N. } \\
\text { R.P.G.N. }\end{array}$ & $\begin{array}{l}\text { Haemoptysis } 1 \text { year } \\
\text { Haemoptysis } 5 \text { years }\end{array}$ & $\begin{array}{l}9 \\
8 \cdot 4\end{array}$ & $\begin{array}{l}165 \\
250\end{array}$ & $\begin{array}{l}\text { Diffuse infiltrates } \\
\text { Bilateral lower zone }\end{array}$ & $\begin{array}{l}\text { Normal } \\
\text { Normal }\end{array}$ \\
\hline $\begin{array}{l}3 \\
4\end{array}$ & $\begin{array}{l}\text { M. } \\
\text { F. }\end{array}$ & 27 & $\begin{array}{l}\text { R.P.G.N. } \\
\text { R.P.G.N. }\end{array}$ & $\begin{array}{l}\text { Haemoptysis } 3 \text { months } \\
\text { Cough } 10 \text { days, haemoptysis } \\
\text { on dialysis }\end{array}$ & $\begin{array}{l}9 \cdot 7 \\
5 \cdot 8\end{array}$ & $\begin{array}{l}142 \\
147\end{array}$ & $\begin{array}{l}\text { Normal } \\
\text { Diffuse infiltrates }\end{array}$ & $\begin{array}{l}\text { Normal } \\
\text { Normal }\end{array}$ \\
\hline $\begin{array}{r}5 \\
6 \\
7 \\
8 \\
9 \\
10\end{array}$ & $\begin{array}{l}\text { M. } \\
\text { F. } \\
\text { F. } \\
\text { M. } \\
\text { M. }\end{array}$ & $\begin{array}{l}19 \\
40 \\
51 \\
59 \\
49 \\
51\end{array}$ & $\begin{array}{l}\text { R.P.G.N. } \\
\text { R.P.G.N. } \\
\text { R.P.G.N. } \\
\text { Proteinuria } \\
\text { Nephrotic syndrome } \\
\text { ?Henoch-Schönlein } \\
\text { syndrome }\end{array}$ & $\begin{array}{l}\text { Haemoptysis } 1 \text { month } \\
\text { Winter bronchitis } \\
\text { None } \\
\text { Winter bronchitis } \\
\text { None } \\
\text { None }\end{array}$ & $\begin{array}{r}7 \cdot 2 \\
8 \cdot 6 \\
10 \cdot 1 \\
7 \cdot 9 \\
9 \cdot 0 \\
12 \cdot 5\end{array}$ & $\begin{array}{r}28 \\
312 \\
600 \\
84 \\
94 \\
42\end{array}$ & $\begin{array}{l}\text { Diffuse infiltrates } \\
\text { Normal } \\
\text { Normal } \\
\text { Bilateral basal shadowing } \\
\text { Normal } \\
\text { Normal }\end{array}$ & $\begin{array}{l}\text { Normal } \\
\text { Normal } \\
\text { Normal } \\
150 / 90 \\
140 / 95 \\
\text { Normal }\end{array}$ \\
\hline
\end{tabular}

R.P.G.N. = rapidly progressive glomerulonephritis.

tor tests negative in all cases. Cases 1,4 , and 5 have been the subject of single case reports (Peters and Evans 1972; Eisinger, 1973, Eisinger et al., 1973).

\section{CLINICAL FEATURES}

Five patients (cases 1-5) presented with rapidly progressive glomerulonephritis and all had evidence of intra-alveolar haemorrhage, thus falling into the category of "Goodpasture's syndrome." All had haemoptyses, which preceded admission by one and five years in two cases but by only a few weeks in most cases. In cases 1 and 4 the pulmonary haemorrhage became massive and caused the patients' deaths. All patients were anaemic on admission and had severely impaired renal function (except for case 5, whose creatinine was normal on admission but thereafter rose rapidly). The two patients in cases 6 and 7 also presented with rapidly progressive glomerulonephitis but showed no evidence of pulmonary haemorrhage. One patient (case 6) had recurrent winter bronchitis but the other (case 7) had no lung syndrome. Of the three remaining patients one (case 8) presented with longstanding cough and hypochromic anaemia and was found to have renal impairment. His chest $x$-ray picture showed bilateral basal shadowing but he never had haemoptysis. One patient (case 9) presented with a two-year history of hypertension and recent-onset nephrotic syndrome and one (case 10) developed swollen joints, proteinuria, and a rash clinically indistinguishable from Henoch-Schönlein purpura.

\section{Renal and Lung Histology}

Renal biopsy specimens from cases $2,3,6$, and 7 showed a severe proliferative glomerulonephritis with cellular crescents containing polymorphs and fibrin in $80 \%-100 \%$ of glomeruli. The glomerular tufts were collapsed and capillary loops bloodless with focal necrosis in some glomeruli but little endothelial or mesangial proliferation. All showed extensive tubular atrophy and a heavy interstitial inflammatory infiltrate. In case 7 there was fibrinoid necrosis in the afferent arteriole. The initial biopsy specimen from case 5 showed a focal and segmental proliferative glomerulonephritis with adhesions and epithelial crescents in some glomeruli. Kidneys obtained at nephrectomy in cases 2,3 , and 5 and necropsy in cases 1, 4, and 7 showed much more extensive collagenization in the glomerular tufts and crescents, often with sclerosis of whole glomeruli.

The biopsy specimens from cases 8 and 10 showed a severe focal proliferative glomerulonephritis with some adhesions but only occasional crescents. In case 9 the biopsy showed mesangiocapillary glomerulonephritis with many focally scattered polymorphs in the glomeruli and occasional crescents.

Details of immunofluorescence findings are given in table II. All showed linear IgG deposition though this was less marked in cases 8, 9, and 10. C3 was nearly always present though usually not in a linear distribution. IgM and IgA were usually undetectable and fibrin deposits were present in crescents. The initial biopsy on case 5 showed no immunoglobulin or complement (studies were done in two different laboratories) whereas his nephrectomy specimen showed linear IgG and contained C3. The lungs were studied at necropsy in cases 1,2 , 4 , and 7 . In case 1 there was bronchiectasis and much recent haemorrhage but no haemosiderin-laden macrophages, in case 2 there was oedema but no recent haemorrhage though haemosiderin-laden macrophages were present, and in case 4 the alveoli were filled with blood and haemosiderin-laden macrophages. The lungs in case 7 were normal with no haemosiderin-containing macrophages.

TABLE II-Details of Renal Biopsies

\begin{tabular}{|c|c|c|c|c|c|c|c|}
\hline $\begin{array}{l}\text { Case } \\
\text { No. }\end{array}$ & Light Microscopy & IgG & IgM & Fibrin & IgA & C3 & $\begin{array}{l}\text { Elution of Anti-G.B.M. } \\
\text { Antibody from Kidney }\end{array}$ \\
\hline 1 & $\begin{array}{l}\text { Proliferative glomerulonephritis with } \mathbf{8 0} \% \\
\text { crescents }\end{array}$ & Linear ++ & N.D. & N.D. & N.D. & N.D. & + \\
\hline 2 & $\begin{array}{l}\text { Proliferative glomerulonephritis with } \mathbf{8 0} \% \\
\text { crescents }\end{array}$ & Linear ++ & - & + In crescents & \pm & + & + \\
\hline 3 & $\begin{array}{l}\text { Proliferative glomerulonephritis with } 80 \% \\
\text { crescents }\end{array}$ & Linear ++ & - & + In crescents & - & + & N.D. \\
\hline 4 & $\begin{array}{l}\text { Proliferative glomerulonephritis with } 80 \% \\
\text { crescents }\end{array}$ & Linear ++ & + Patchy & + In crescents & - & $\begin{array}{l}+ \text { Granular } \\
\text { and linear }\end{array}$ & N.D. \\
\hline 5 & $\begin{array}{c}\text { Proliferative glomerulo- } \\
\text { nephritis with } 80 \% \\
\text { crescents }\end{array} \quad\left\{\begin{array}{l}\text { Biopsy } \\
\text { Nephrectomy } \\
\text { specimen }\end{array}\right.$ & $\stackrel{-}{\text { Linear }++}$ & - & $\begin{array}{l}- \\
-\end{array}$ & - & + Granular & + \\
\hline 6 & $\begin{array}{l}\text { Proliferative glomerulonephritis with } 80 \% \\
\text { crescents }\end{array}$ & Linear ++ & \pm & $\begin{array}{l}+ \text { In crescents } \\
\text { and some loops }\end{array}$ & \pm & & N.D. \\
\hline 7 & $\begin{array}{l}\text { Proliferative glomerulonephritis with } 80 \% \\
\text { crescents }\end{array}$ & Linear ++ & - & $\begin{array}{l}+ \text { In crescents } \\
\text { and afferent }\end{array}$ & - & - & N.D. \\
\hline 8 & Focal proliferative glomerulonephritis & Linear \pm & ++ Granular & & \pm & ++ Granular & N.D. \\
\hline $\begin{array}{r}9 \\
10\end{array}$ & $\begin{array}{l}\text { Mesangiocapillary glomerulonephritis } \\
\text { Focal proliferative glomerulonephritis with } \\
\text { crescents }\end{array}$ & $\begin{array}{l}\text { Linear }+ \\
\text { Linear } \pm\end{array}$ & $\begin{array}{l}\text { and segmental } \\
+ \text { Granular }\end{array}$ & $\underset{++}{\text { Granular }}$ & - & $\begin{array}{l}\text { and segmental } \\
+\underset{+}{+}\end{array}$ & $\begin{array}{l}\text { N.D. } \\
\text { N.D. }\end{array}$ \\
\hline
\end{tabular}


TABLE III-Treatment and Outcome of Patients with Anti-G.B.M. Antibody

\begin{tabular}{|c|c|c|c|c|c|}
\hline $\begin{array}{l}\text { Case } \\
\text { No. }\end{array}$ & Prednisone & Cyclophosphamide & Anticoagulants & Nephrectomy & Outcome \\
\hline$\frac{1}{2}$ & + & $\overline{+}$ & $\bar{I}$ & $\overline{+}$ & $\begin{array}{l}\text { Died of pulmonary haemorrhage } \\
\text { Chronic haemodialysis. Died later after dialysis }\end{array}$ \\
\hline $\begin{array}{r}3 \\
4 \\
5 \\
6 \\
7 \\
8 \\
9 \\
10\end{array}$ & $\begin{array}{l}+ \\
+ \\
+ \\
+ \\
+ \\
+ \\
+\end{array}$ & $\begin{array}{l}+ \\
+ \\
+ \\
+ \\
+ \\
+ \\
+\end{array}$ & $\begin{array}{l}\text { Ancrod } \\
-- \\
\text { Ancrod } \\
\quad- \\
= \\
= \\
-\end{array}$ & $\begin{array}{l}+ \\
+* \\
+ \\
+ \\
= \\
=\end{array}$ & $\begin{array}{l}\text { Chronic haemodialysis } \\
\text { Died of pulmonary haemorrhage } \\
\text { Chronic haemodialysis. Died later after failed transplant } \\
\text { Chronic hameodialysis } \\
\text { Died of massive cerebral infarction } \\
\text { Well. Renal function static } \\
\text { Well. Renal function static } \\
\text { Well. Renal function improved with treatment }\end{array}$ \\
\hline
\end{tabular}

*Pulmonary haemorrhage continued after nephrectomy.

\section{MANAGEMENT AND OUTCOME (TABLE III)}

The five patients with Goodpasture's syndrome were all treated with prednisone $(60-80 \mathrm{mg}$ daily) and (except for the patient in case 1) with cyclophosphamide $2-3 \mathrm{mg} / \mathrm{kg} /$ day. The patient in case 3 was also treated with the defibrinating agent ancrod. One patient (case 2) while still having haemoptyses and some residual renal function was also subjected to plasmapheresis on five occasions, using an I.B.M. cell centrifuge, in an attempt to remove sufficient antibody to arrest progress of the disease. Despite treatment these patients developed irreversible renal failure. One (case 1) died of fulminating pulmonary haemorrhage and two (cases 2 and 3) were placed on maintenance dialysis and both had bilateral nephrectomy before possible transplantation but at a time when both had stopped having haemoptyses. In contrast, the two patients in cases 4 and 5 had bilateral nephrectomy in an attempt to arrest continuing pulmonary haemorrhage. One (case 4) was already extremely ill and died shortly after operation, but the other (case 5) was maintained on haemodialysis and continued to have haemoptyses for several months after nephrectomy.

The patients in cases 6 and 7 were also treated with prednisone and cyclophosphamide, and one (case 6) was also given ancrod for only 36 hours before haemorrhage occurred from the biopsy site. No recovery of renal function occurred in either patient and one (case 6) was on maintenance dialysis at the time of writing. The other (case 7) died with evidence of extensive cerebral infarction, probably due to emboli as thrombosis and arteritis were not found at necropsy.

Of the remaining three patients, those in cases 8 and 9 received no specific treatment and their renal function did not change significantly during follow up over 18 months. The patient in case 10 had deteriorating renal function and was treated with prednisone and cyclophosphamide. His renal function improved-creatinine clearance rose to normal from $31 \mathrm{ml} / \mathrm{min}$-and he was well at the time of writing.

\section{Results of Anti-G.B.M. Antibody Estimations}

The results of the anti-G.B.M. antibody estimations performed by the two techniques on the same samples of sera are shown in table IV. The five patients with Goodpasture's syndrome all had evidence of circulating anti-G.B.M. antibody on indirect immunfluorescence and in three cases the sera gave linear staining at titres of $1 / 16$. Significant titres of anti-G.B.M. antibody were also detected by passive haemagglutination in the four patients whose sera were tested. One patient (case 5) had high titres of anti-G.B.M. antibody on presentation (by passive haemagglutination) and before his nephrectomy (by both techniques) which persisted after the operation, the serum giving negative results by both techniques only some six months later.

Attempts were also made to elute antibody from the whole kidney in cases 1 and 2 . The eluate in case 1 consisted of IgG with some IgA and gave linear staining on indirect immunofluorescence. It was also labelled with ${ }^{131} \mathrm{I}$ and a high
TABLE IV-Serum Anti-G.B.M. Antibody Titres

\begin{tabular}{|c|c|c|c|}
\hline $\begin{array}{l}\text { Case } \\
\text { No. }\end{array}$ & & $\begin{array}{c}\text { Passive } \\
\text { Haemagglutination* }\end{array}$ & $\begin{array}{c}\text { Indirect } \\
\text { Immunofluorescence } \dagger\end{array}$ \\
\hline $\begin{array}{r}5 \\
6 \\
7 \\
8 \\
9 \\
10\end{array}$ & $\begin{array}{l}\text { On presentation } \\
3 / 52 \text { before nephrectomy } \\
3 / 52 \text { after nephrectomy } \\
6 / 52 \text { after nephrectomy } \\
4 / 12 \text { after nephrectomy } \\
6 / 12 \text { after nephrectomy }\end{array}$ & $\begin{array}{c}\text { N.D. } \\
1 / 32 \\
1 / 8-1 / 16 \\
1 / 16-1 / 64 \\
1 / 64 \\
1 / 32 \\
1 / 8 \\
1 / 8 \\
1 / 64 \\
0 \\
1 / 32-1 / 64 \\
1 / 8 \\
1 / 16 \\
1 / 4 \\
1 / 8-1 / 32\end{array}$ & $\begin{array}{c}1 / 1 \\
1 / 1-1 / 2 \\
1 / 1-1 / 2 \\
1 / 16 \\
\text { N.D. } \\
1 / 16 \\
1 / 8 \\
1 / 4 \\
0 \\
0 \\
1 / 4 \\
1 / 1-1 / 2 \\
0 \\
\text { N.D. } \\
0\end{array}$ \\
\hline
\end{tabular}

* Controls gave values up to $1 / 8$. N.D. = Not done. $0=$ Negative result.

degree of binding of radioactivity to kidney and lung homogenates was shown (Peters and Evans, 1972). Anti-G.B.M. antibody was present by indirect immunofluorescence in the eluate from case 2 and in the eluate from cryostat sections of the nephrectomy specimen in case 5 .

Both patients with rapidly progressive glomerulonephritis without pulmonary haemorrhage had significant circulating anti-G.B.M. antibody on indirect immunofluorescence though only case 6 had a significant titre by passive haemagglutination.

Of the three patients with less marked linear staining in their renal biopsy specimens two (cases 8 and 10) had significant titres of anti-G.B.M. antibody by passive haemagglutination but completely negative results with indirect immunofluorescence and one (case 9) had an insignificant titre of antibody on passive haemagglutination.

\section{Discussion}

Apparently non-specific linear staining of the G.B.M., with no evidence of anti-G.B.M. antibody in serum or eluates, has been reported in kidneys from diabetics (Gallo, 1970; Westberg and Michael, 1972; Wilson and Dixon, 1973) and in kidneys from patients dying without evidence of renal disease (Koffler et al., 1969; Wilson and Dixon, 1973). We have also found that apparently normal kidneys obtained at necrospy sometimes show linear staining after washing with phosphate buffered saline alone, possibly due to IgG normally present in the G.B.M. (Westberg and Michael, 1970) being exposed by the washing.

Hence it is important to have some method of measuring anti-G.B.M. antibody. Indirect immunofluorescence has been most used but may be of limited sensitivity and requires care in the selection of target tissue to avoid confusing autofluorescence (McPhaul and Dixon, 1969). We found the most reliable results were obtained with fresh monkey kidney. The passive haemagglutination test seems to be sensitive but is more complex and the end point may be difficult to re- 
cord. A reasonable measure of agreement was found between the two tests (table IV). Conflicting results on the same serum samples may reflect a difference in sensitivity or the possibility that the methods are measuring antibodies to different antigenic components of the G.B.M. Furthermore, negative results may simply reflect high avidity of antibody to renal tissue, and in these circumstances circulating anti-G.B.M. antibody might only be found after nephrectomy.

Five patients (the Goodpasture's syndrome group) showed the clinical features previously noted in other cases-anaemia on presentation, absence of hypertension, severe nephritis, and potentially severe lung haemorrhage, which caused the deaths of two patients. No patient had preceding influenza (Wilson and Smith, 1972) or a history of excessive exposure to hydrocarbon solvents (Beirne and Brennan, 1972), which are reported associations with Goodpasture's syndrome and suggested causes of initiating lung damage.

The usual explanation for the pathogenesis of Goodpasture's syndrome is that for some reason anti-basement membrane antibodies are formed which cross-react with antigens common to lung and kidney, causing alveolar and glomerular damage. The initial renal biopsy in case 5 showed no linear staining for IgG at a time when circulating anti-G.B.M. antibody was present and he was having haemoptyses whereas unequivocal linear staining was present in the later nephrectomy specimen. This surprising finding could mean that antiG.B.M. antibody is not necessarily responsible for, at least, the initial focal glomerular damage in Goodpasture's syndrome though human anti-G.B.M. antibody can transmit nephritis to primates (Lerner et al., 1967) and undoubtedly can be pathogenetic.

In two patients rapidly progressive glomerulonephritis occurred without lung haemorrhage. Lung haemorrhage may not occur in such patients because the antibody is directed against antigens in the G.B.M. not shared by lung basement membrane, or perhaps because additional damage must occur in the lungs-for example, from infection or some toxic agent - for antigens in the alveolar basement membrane to react with antibody. Indeed it is not entirely clear that lung haemorrhage is necessarily due to anti-basement membrane antibody.

Three patients with less marked linear staining and less severe nephritis had no detectable circulating anti-G.B.M. antibody by indirect immunofluorescence, but in two cases a significant titre was detected by passive haemagglutination. We therefore cannot be certain that the nephritis was mediated by anti-G.B.M. antibody in these cases, and possibly antibody was produced secondary to glomerular damage (Macanovic et al., 1972; Mahieu et al., 1972).

Management of patients with circulating anti-G.B.M. antibody presents the problems of controlling the nephritis and pulmonary haemorrhage. Progression of nephritis despite socalled immunosuppressive treatment is the usual experience though there are reports of remission or non-progression of nephritis related to treatment with steroids and cytotoxic drugs (Seaton et al., 1971). Now that renal failure does not lead inevitably to death but to chronic dialysis massive pulmonary haemorrhage is the most serious threat to these patients. Bilateral nephrectomy has been advocated for its control, the suggestion being that by removing the source of G.B.M. antigens the stimulus to continuing anti-G.B.M. antibody formation will be reduced. Despite several reports of the apparent efficacy of nephrectomy (Maddock et al., 1967; Halgrimson et al., 1971), there are cases (such as 4 and 5) where haemoptysis continues after nephrectomy and circulating anti-G.B.M. antibody persists (Wilson and Dixon 1973). Plasmapheresis in case 2 did not reduce the antiG.B.M. antibody titre (by passive haemagglutination) on five occasions, perhaps partly because there is a sizeable extravascular pool of IgG.

Only one of our patients was transplanted. The transplant was rejected after a few weeks but showed no evidence of recurrence of the original disease. Successful renal transplants have been reported in other patients, but nephritis has also recurred, particularly if circulating anti-G.B.M. antibody was detectable at the time of transplantation. Thus transplantation seems best postponed until tests for antibody are negative.

Though there are numerous case-reports of Goodpasture's syndrome (reviewed by Benoit et al., 1964, and Proskey et al., 1970) in most cases there are no studies on anti-G.B.M. antibodies. Wilson and Dixon (1973), however, have recently detailed 63 cases with linear G.B.M. staining and evidence of anti-G.B.M. antibody in serum and eluates, though clinical details of the patients were obtained from questionnaires.

It is clear there is no general agreement about the precise use of the term "Goodpasture's syndrome," some applying it only to patients with nephritis, intra-alveolar haemorrhage, and anti-G.B.M. antibody in serum or eluates (Wilson and Dixon, 1973; Martinez and Kohler, 1971) and others simply to the clinical syndrome of nephritis and pulmonary haemorrhage even if there is evidence for immune-complex deposition in the kidney (Beirne et al., 1973).

It seems that though there is impressive evidence for a pathogenetic role of anti-G.B.M. antibody in human nephritis the association is a rare one and the problems of what factors initiate anti-G.B.M. antibody formation, the time sequence of events leading to basement membrane damage, and whether such antibody is always of primary pathogenetic importance remain largely unresolved.

We thank Mr. N. Amos and Miss G. Watts for their skilled technical help.

\section{References}

Beirne, G. J., Kopp, W. L., and Zimmerman, S. W. (1973). Archives of Internal Medicine, 132, 261

Beirne, G. J., and Brennan, J. T. (1972). Archives of Environmental Health, 25, 365.

Benoit, F. L., et al. (1964). American fournal of Medicine, 37, 424.

Eisinger, A. J. (1973). American fournal of Medicine, 55, 565.

Eisinger, A. J., et al. (1973). Nephron, 11, 1.

Evans, D. J., et al. (1973). British Medical fournal, 3, 326

Feltkamp, T. E. W., and Boode, J. H. (1970). Fournal of Clinical Pathology, 23, 629 .

Gallo, G. R. (1970). American fournal of Pathology, 61, 377.

Halgrimson, C. G. et al. (1971). Archives of Surgery, 103, 283.

Koffer, D. et al. (1969). American fournal of Pathology, 56, 305.

Lerner, R. A., Glassock, R. J., and Dixon, F. J. (1967). fournal of Experimental Medicine, 126, 989 .

Macanovic, M., Evans, D. J., and Peters, D. K. (1972). Lancet, 2, 207.

Maddock, R. K. jun. et al. (1967). Annals of Internal Medicine, 67, 1258.

McPhaul, J. J., and Dixon, F. J. (1969). Fournal of Immunology, 103, 1168. Mahieu, P., Dardenne, M., and Bach, J. F. (1972). American fournal of Medicine, 53, 185.

Martinez, J. S., and Kohler, P. F. (1971). Annals of Internal Medicine, 75, 67. Peters, D. K., and Evans, D. J. (1972). British Medical Fournal, 2, 272.

Proskey, A. J. et al. (1970). American fournal of Medicine, 48, 162.

Seaton, A. Meland, J. M. and Lapp, N. L. (1971). Thorax, 26, 683

Seaton, A., Meland, J. M., and Lapp, N. L. (1971. Thorax, 26, 683.

Westberg, N. G., and Michael, A. F. (1970). Biochemistry, 9, 383

Westberg, N. G., and Milson, C. B., and Dixon, F. J. (1973). Kidney International, 3, 74.

Wilson, C. B., and Smith, R. C. (1972). Annals of Internal Medicine, 76, 91. 